\title{
Non-Carcass Parts of Local Male Ducks Fed Commercial Feed Supplemented with Torch Ginger (Etlingera elatior) Flower Extract
}

\section{Mohammad Badru Zaman, Ristika Handarini, and Deden Sudrajat}

Department of Animal Husbandry, Faculty of Agriculture, Universitas Djuanda, Indonesia

\begin{abstract}
The torch ginger (Etlingera elatior) is a herbaceous plant the flower of which is commonly used in feed to improve the quality of meat. This study was aimed at assessing the effects of giving commercial feed non-carcass portions of local ducks. The study was conducted at the Poultry Farm of Department of Animal Husbandry Djuanda University, Bogor, from June to August 2016. Twenty four 2-week-old male local ducks were used. Completely randomized design with 4 treatments and 3 replicates was used. The treatments consisted of $100 \%$ of commercial ration (R0), commercial ration $+2.5 \%$ of TGE solution (R1), commercial ration $+5 \%$ of TGE solution (R2), and commercial ration $+7.5 \%$ of TGE solution (R3). The feeding trial lasted 6 weeks after which the ducks were slaughtered and carcass weight, dressing percentages and carcass parts were measured. The percentage of non-carcass parts including head, neck, shank, liver, heart, gizzard, feathers, blood and intestines were also measured. No significant effect of treatments $(\mathrm{P}>0.05)$ on all parameters measured were found. It was concluded that the inclusion of TGE solution in commercial ration up to $7.5 \%$ did not significantly affect the live weight, weight and percentages of non-carcass parts including blood, feathers, head, neck, shank, liver, gizzard, heart, and intestines.
\end{abstract}

Keywords: commercial ration, male local duck, non-carcass, torch ginger flower extract solution

Received 07 March 2018 | Revised 28 March 2018 | Accepted 28 March 2018

\section{Introduction}

Local ducks as a source of meat plays a very important role in meeting Indonesia needs for animal protein. One of te varieties of local poultry mostly developed is ducks. In Indonesia few research are conducted to determine optimal feeding of local ducks hence, little is known about effect of herbal supplementation on growth performance and meat quality.

Torch ginger (Etlingera elatior) is a species of herbaceous plant that contains about $0.0334 \%$ essential oil and antioxidants in the flowers. These compounds which have antibacterial properties and act as antioxidants [3], [4], [5], [6]. The active ingredients contained in torch ginger are: glycoside, phenolic, steroids, saponins, triterpenoids, tannins and alkaloids. The utilization of torch ginger as an additive in poultry diets has been tried out for various purposes

\footnotetext{
*Corresponding author at: Department of Animal Husbandry, Faculty of Agriculture, Universitas Djuanda, Jl. Raya Puncak, Ciawi, Bogor, Jawa Barat, Indonesia

E-mail address: moh.badru.zaman@unida.ac.id
} 
[7], [8]. This study aims at examining the use of commercial feeding and torch ginger flower extract solution to the non-carcass parts of local ducks.

\section{Materials and Method}

This research was conducted from June to August 2016 in the poultry laboratory of Animal Husbandry Program of Universitas Djuanda, Bogor. This study used twenty four 2-week-old local male ducks (average weight of $450 \pm 53.04 \mathrm{~g}$ ).

The ducks were placed in individual battery cage measuring $43 \times 50 \times 50 \mathrm{~cm}$ with the inclination of $9^{\circ}$ equipped with trays for droppings, feeders and drinkers.

Table 1. Nutrient Content in the BR-21E Commercial Diet

\begin{tabular}{clcc}
\hline No. & \multicolumn{1}{c}{ Composition } & \multicolumn{2}{c}{ Nutrient Content (\%) } \\
\hline 1. & Water Content $(\max )$ & $12^{*}$ & $10.02^{* *}$ \\
2. & Crude Protein & $20-22^{*}$ & $20.06^{* *}$ \\
3. & Crude Fat (min) & $5^{*}$ & $4.72^{* *}$ \\
4. & Crude Fibre (max) & $5^{*}$ & $3.14^{* *}$ \\
5. & Ash (max) & $8^{*}$ & $5.11^{* *}$ \\
6. & Calcium & $0.8-1.1^{*}$ & \\
7. & Phosphor & $0.5^{*}$ & \\
\hline
\end{tabular}

Source: *PT. Shinta Prima Feedmill (2016), ** Laboratory of IPB (2016)

\subsection{Dietrary Treatments}

The treatment was the provision of ration with the compositions: $\mathrm{R} 0=$ commercial diet, $\mathrm{R} 1=$ commercial diet $+2.5 \%$ of TGE solution, $\mathrm{R} 2=$ commercial diet $+5 \%$ of TGE solution, $\mathrm{R} 3=$ commercial diet $+7.5 \%$ of TGE solution. The content of crude protein of ducks ranged from $20 \%$ to $22 \%$.

\subsection{Data Collection}

At the age of 56 days the ducks were slaughtered and the data collected were (1) Body Weight (g): Body weight was known by weighing the duck before slaughtering; (2) Non-Carcass $(\%)=$ The non-carcass weight divided by the body weight multiplied by $100 \%$; (3) Blood $(\%)=$ The blood weight divided by the body weight multiplied by $100 \%$; (4) Feather $(\%)=$ The feather weight divided by the body weight multiplied by $100 \%$; (5) Head $(\%)=$ The head weight divided by the body weight multiplied by $100 \%$; (6) Neck $(\%)=$ The neck weight divided by the body weight multiplied by $100 \%$; (7) Shank $(\%)=$ The shank weight divided by the body weight multiplied by $100 \%$; (8) Liver (\%) = The liver weight divided by the body weight multiplied by 100\%; (9) Gizzard (\%) = The gizzard weight divided by the body weight multiplied by $100 \%$; (10) Heart $(\%)=$ The heart weight divided by the body weight multiplied 
by $100 \%$; (11) Intestine $(\%)=$ The intestine weight divided by the body weight multiplied by $100 \%$.

\subsection{Experimental Design}

This study used a completely randomized design with 4 treatments and 3 replications, each replication used 2 local male ducks. The data analysis was done using Anova test. When the results showed an significan effect $(P<0.05)$ or very significant effect $(P<0.01)$, then the analysis was proceeded to Duncan test to know the difference between the treatments.

\subsection{Implementation Procedures}

Cages were cleaned using a disinfectant, and a base was provided under the cage to accommodate the excreta. The food tray and the drink container were placed in every partition of the cage and the lights were installed around the cage. The torch ginger flower used should be fresh. In preparing the solution, the torch ginger flower was washed and cleaned. Then, it was chopped into smaller size $( \pm 0.3 \mathrm{~cm})$, and then was mashed using a mortar. Next, it was mixed with water with the ratio of $600 \mathrm{~g}$ of torch ginger flower in 1 liter of water, and the mixture was boiled in small flame for 30 minutes. After that, it was cooled and filtered. The torch ginger flower extract solution is ready to be used as a mixture in the ducks' food. The ducks used in this study were healthy, bright eyeds, disability-free and active. The ducks were weighed, allowed 7 days adaptation followed by data collection for 4 weeks.

At the end of the feeding trial (56 days of age). The ducks were starved for 12 hours and slaughtered according to the Halal procedures. After slaughter the carcasses were hung with the head down position for the maximal blood withdrawal. After the blood stopped flowing, the ducks were weighed to determine their blood weight, and then the carcasses were dunked into hot water with a temperature of $80-95{ }^{\circ} \mathrm{C}$ for 5 to 10 seconds for removal of the feathers.

Separating the ducks' body parts began with the removal of internal organs. Furthermore, the breast and abdomen parts were cut, the internal organs were discarded, washed, drained and weighed. Cutting the head was done by cutting the atlanto occipitalis, while cutting the neck was done by cutting the joint between os vertebrae cervicalis and os vertebrae thoracalis, then cutting the shanks was done by cutting the joint between os tarsal and os tibia.

\section{Results and Discussion}

The result of data analysis of giving torch ginger flower extract solution against the percentage of non-carcass parts of ducks is presented in Table 2. 
Table 2. Percentage of Non-carcas Part of Local Male Ducks

\begin{tabular}{ccccccc}
\hline \multirow{2}{*}{ Treatment } & \multicolumn{7}{c}{ Percentage (\%) } \\
\cline { 2 - 7 } & Non-carcass & Blood & Feather & Head & Neck & Shank \\
\hline R0 & $43.08 \pm 0.97$ & $8.47 \pm 0.19$ & $7.96 \pm 0.340$ & $5.11 \pm 0.02$ & $5.08 \pm 0.95$ & $2.29 \pm 0.04$ \\
R1 & $42.83 \pm 2.48$ & $8.67 \pm 0.80$ & $8.17 \pm 0.74$ & $5.20 \pm 0.56$ & $5.26 \pm 0.37$ & $2.45 \pm 0.30$ \\
R2 & $46.11 \pm 0.36$ & $9.19 \pm 0.41$ & $8.28 \pm 0.43$ & $5.68 \pm 0.06$ & $4.90 \pm 0.44$ & $2.58 \pm 0.19$ \\
R3 & $44.21 \pm 2.35$ & $8.61 \pm 0.93$ & $8.64 \pm 0.79$ & $5.10 \pm 0.56$ & $4.82 \pm 0.99$ & $2.31 \pm 0.03$ \\
\hline Mean & $\mathbf{4 4 . 0 6} \pm \mathbf{2 . 0 3}$ & $\mathbf{8 . 7 4} \pm \mathbf{0 . 6 3}$ & $\mathbf{8 . 2 6} \pm \mathbf{0 . 5 9}$ & $\mathbf{8 . 2 6} \pm \mathbf{0 . 5 9}$ & $\mathbf{5 . 0 1} \pm \mathbf{0 . 6 6}$ & $\mathbf{2 . 4 1} \pm \mathbf{0 . 1 9}$ \\
\hline
\end{tabular}

Notes: R0 $=$ Commercial Diet; R1 $=$ Commercial Diet $+2.5 \%$ of torch ginger flower extract solution; R2 = Commercial Diet $+5 \%$ of torch ginger flower extract solution; R3 = Commercial Diet $+7.5 \%$ of torch ginger flower extract solution

Based on the analysis of variance (Table 2), the effect of giving torch ginger flower extract solution against the percentage variables of non-carcass parts, blood (blood, feather, head, neck and shank) showed no significant difference $(\mathrm{P}>0.05)$. The mean percentage of non-carcass parts was $44.06 \pm 2.033 \%$. This mean percentage was lower than the result of the study done by Pasang [9] with the mean percentage of $46.94 \%$, but higher than the results of the studies done by Daud et al. [10] with the mean percentage of $42.82 \%$ and Putra et al. [11] with the mean percentage of $43.35 \%$.

The result of variance analysis (Table 2$)$ showed no significant difference $(\mathrm{P}>0.05)$ on the percentage of blood variable $(8.74 \pm 0.626 \%)$ and the percentage of feather variable $(8.26 \pm$ $0.585 \%$ ). The results of this research were higher than the results of Isnaini's [12] research where the cross-breeding ducks (of Muscovy duck and Cihateup duck) had a blood percentage of $6.49 \pm 1.75 \%$. The results of this study were still within the range of blood percentage in Wardhana et al. [13] who suggested that the percentage of blood in the body was $5 \%$ to $10 \%$ of the body weight, depending on the species and the nutritional state of livestock. The percentage of feather found in this research was higher than the results of the research done by Randa et al. [14] who found that the percentage of feather was $7.98 \%$. The giving of torch ginger flower extract solution up to $7.5 \%$ had not given a significant effect on the percentage of ducks' blood and feather.

Based on the analysis of variance (Table 2), giving torch ginger flower extract solution up to $7.5 \%$ did not give significant effect $(\mathrm{P}>0.05)$ to the mean percentage of head variable $(8.26 \pm$ $0.55 \%)$, neck variable $(5.01 \pm 0.66 \%)$ and shank variable $(2.41 \pm 0.19 \%)$. The results of the research done by Kharisma et al. [15] on Magelang ducks fed by commercial BR-1 ration had a head percentage of $5.25 \pm 0.48 \%$. Soeparno [16] suggested that the growth of the body component was indicated by the livestock's almost constant bone growth when the livestock experienced maturity. The mean percentage of neck in this research was $5.01 \pm 0.66 \%$, lower than Simanullang's [17] research on PMp ducks with a $6.45 \%$ neck mean percentage. The results of this research also showed the relatively similar states between the neck weight and the neck percentage because the genetic growth rate of the neck of ducks is just the same whether it 
was given or was not given the ration or the treatment. Furthermore, giving torch ginger flower extract solution up to $7.5 \%$ did not give significant effect $(\mathrm{P}>0.05)$ to the mean percentage of shank variable $(2.41 \pm 0.19 \%)$. The mean percentage of shank found in this research was lower than that of Dewanti et al. [18] at 2.68\%. But, in general, the weight and percentage of the ducks' shank was almost the same because the shank was composed of many bones. Andoko [19] stated that the fastest growth was the bone growth and once it reached the maximum size, the bone growth would stop, the bone grows first because it is the framework that determines the formation of muscle. Moreover, Andoko [19] stated that bone was formed at the beginning of growth and was almost constant when the animals were getting mature.

The mean percentage of giblet (liver, gizzard, heart) and intestine can be seen in Table 3. In general, giving torch ginger flower extract solution up to $7.5 \%$ did not give significant effect to the variables of giblet and intestine.

Table 3. The Percentage of Giblet and Intestine of Local Male Ducks

\begin{tabular}{ccccc}
\hline \multirow{2}{*}{ Treatment } & \multicolumn{4}{c}{ Giblet Percentage (\%) } \\
\cline { 2 - 5 } & Liver & Gizzard & Heart & Intestine \\
\hline R0 & $2.50 \pm 0.02$ & $3.02 \pm 0.12$ & $0.66 \pm 0.00$ & $3.68 \pm 0.43$ \\
R1 & $2.07 \pm 0.66$ & $2.80 \pm 0.25$ & $0.69 \pm 0.03$ & $3.52 \pm 0.22$ \\
R2 & $2.40 \pm 0.14$ & $3.01 \pm 0.32$ & $0.81 \pm 0.09$ & $4.31 \pm 0.52$ \\
R3 & $1.83 \pm 0.23$ & $2.70 \pm 0.43$ & $0.71 \pm 0.15$ & $4.18 \pm 0.35$ \\
\hline Mean & $\mathbf{2 . 2 0} \pm \mathbf{0 . 4 1}$ & $\mathbf{2 . 8 8} \pm \mathbf{0 . 2 9}$ & $\mathbf{0 . 7 2} \pm \mathbf{0 . 1 0}$ & $\mathbf{3 . 9 3} \pm \mathbf{0 . 4 8}$ \\
\hline
\end{tabular}

Based on result of data analysis presented in Table 3, the effect was not significantly different $(\mathrm{P}>0.05)$ to the mean percentage of liver $(2.20 \pm 0.414 \%)$. The results of this study were lower than the research done by Dewanti et al. [18] who found that the mean percentage of liver of local male ducks was 2.71\%, but higher than Purba and Prasetyo's [20] findings where 12week-old EPMp broiler duck fed with high crude fiber with $21 \%$ of protein content had a liver percentage of $1.90 \pm 0.04 \%$. Nevertheless, their research results were still in line with the opinion of Irham [21] stating that the range of liver percentage was $1.70-2.80 \%$ of the live weight. According by Andoko [19] stated that the weight of the liver would be affected by the body size and strain. In addition, liver weight was also affected by pathogenic bacteria that would lead to swelling liver.

The results of feeding the ducks with commercial food and torch ginger flower extract solution showed no significant effect $(\mathrm{P}>0.05)$ to the percentage of gizzard. The mean percentage of the gizzard found in this research $(2.88 \pm 0.294 \%)$ was lower than Dewanti's [22] findings where 8week-old Turi ducks had a mean percentage of gizzard of $4.74 \%$. This was in line with the opinion of Dharmawanti and Ari [23] stating that the increased weight of gizzard was not due to the increasing growth, but because of its quite heavy function in grinding the food into smaller 
particles, so that the gizzard enlargement was greatly influenced by the number and the nature of roughness of its food ingredients.

Based on the results of data analysis presented in Table 3, the mean percentage of heart showed no significant difference $(\mathrm{P}>0.05)$ between the treatments. The mean weight of duck heart $(0.72 \pm 0.096 \%)$ was lower than the mean weight $(0.84 \%)$ found in the research done by Kurniawan et al. [24]. Similarly, the percentage of intestine also showed no significant difference $(\mathrm{P}>0.05)$ between the treatments. Nevertheless, the average percentage of intestine in this research $(3.93 \pm 0.483 \%)$ was higher than that of Purba and Prasetyo [20] who found that feeding ducks with the ration containing $9 \%$ of crude fiber and $23 \%$ of protein resulted in the intestine percentage of $3.53 \pm 0.14 \%$.

Giving torch ginger flower extract solution up to $7.5 \%$ did not give a significant effect on all non-carcass variables. This shows that the giving of torch ginger flower extract solution was able to maintain the percentage of non-carcass parts of ducks so that it did not decrease the percentage of carcass parts of local male ducks.

\section{Conclusion}

Feeding the ducks with commercial food supplemented with TGE solution at levels up to $7.5 \%$ did not significantly affect the percentages of non-carcass parts in local male ducks. Treatment with TGE gave a positive effect in maintaining the percentage of non-carcass parts of local male ducks.

\section{REFERENCES}

[1] Direktorat Jenderal Peternakan dan Kesehatan Hewan, Produksi daging itik menurut provinsi. Jakarta, Departemen Pertanian, 2015.

[2] H. Sa'diyah, Anggraeni and D. Sudrajat, "Performan produksi itik alabio (Anas Plathyrynchos Borneo) yang diberi ransum komersil dengan tambahan kromium $(\mathrm{Cr})$ organik," Jurnal Peternakan Nusantara, vol. 2, no. 2, pp. 55-60, 2016.

[3] A. Maimulyati and A. R. Prihadi, "Chemical composition, phytochemical and antioxidant activity from extract of Etlingera Elantior flower from Indonesia," Journal of Pharmacognocy and Phytochemistry, vol. 3, no. 6, pp. 233-238, 2015.

[4] A. Windiyartono, Rr. Riyantib and V. Wanniatieb, "Efektivitas tepung bunga kecombrang (nicolaia speciosa horan) sebagai pengawet terhadap aspek kimia daging ayam broiler," Jurnal Ilmiah Peternakan Terpadu, vol. 4, no. 1, pp. 19-23, 2016.

[5] A. Rusanti, D. Sukandar, T. Rudiana, and Adawiah, "Profil fraksi sitotoksik terhadap sel murine leukemia p-388 dari ekstrak biji honje (Etlingera elatior)," Jurnal Kimia VALENSI: Jurnal Penelitian dan Pengembangan Ilmu Kimia, vol. 3, no. 1, pp. 79-87, 2017.

[6] E. W. C. Chan, Y. Y. Lim, and M. Omar, "Antioxidant and antibacterial activity of leaves of ettingera species (Zingiberaceae) in Peninsular Malaysia," Food Chemistry, vol. 104, no. 1, pp. 1586-1593, 2007. 
[7] D. Dina, E. Soetrisno, and Warnoto, "Pengaruh perendaman daging sapi dengan ekstrak bunga kecombrang (Etlingera elatior) terhadap susut masak, ph dan organoleptik (bau, warna, tekstur) effect of marinating beef meat in Etlingera elatior Extract on Cooking Loss, $\mathrm{pH}$, and Organoleptic (Aroma, Color, and Texture)," Jurnal Sain Peternakan Indonesia, vol. 12, no. 2, pp. 209-220, 2017.

[8] O. S. Perdana, "Efektivitas tepung bunga kecombrang sebagai pengawet terhadap daya suka organoleptik daging broiler," Master Thesis, Jurusan Peternakan Fakultas Pertanian, Universitas Lampung, 2016.

[9] N. A. Pasang, "Persentase karkas, bagian-bagian karkas dan lemak abdominal itik lokal (Anas Sp.) yang diberi tepung kunyit (Curcuma Domestica Val.) dalam Pakan," Master Thesis, Fakultas Peternakan, Universitas Hasanuddin, 2016.

[10] M. Daud, Mulyadi, and Z. Fuadi, "Persentase karkas itik peking yang diberi pakan dalam bentuk wafer ransum komplit mengandung limbah kopi," Agripet, vol. 16, no. 1, pp. 62-68, 2016.

[11] Putra, Rukmiasih, and R. Afnan, "Persentase dan kualitas karkas itik cihateup-alabio (ca) pada umur pemotongan yang berbeda," Jurnal Ilmu Produksi dan Teknologi Hasil Peternakan, vol. 03, no. 1, pp. 27-32, 2015.

[12] A. P. Isnaini, "Persentase Karkas dan Non Karkas Itik Mandalung Persilangan Entok dengan Itik Cihateup pada Umur Berbeda," Master Thesis, Fakultas Peternakan, Insitut Pertanian Bogor, 2014.

[13] F. J. Wardhana, A. Mushawir and D. Rusman, "Konsentrasi albumin dan globulin darah itik dengan perbedaan imbangan elektrolit ransum yang dipelihara intensif minim air," Student E-Jurnal, vol. 4, no. 2, pp. 1-7, 2015.

[14] S.Y. Randa, et al, "Efek Pemberian Serat Tinggi dan Vitamin E terhadap Produksi Karkas dan Non Karkas Itik Mandalung," in Proceedings of National Conference of Teknologi Peternakan dan Veteriner, 2002, pp. 261-264.

[15] A. N. Kharisma, Ismoyowati, and M. Sigit, "Perbedaan bobot dan persentase bagian-bagian karkas dan non karkas pada itik lokal (Anas plathyrincos) dan Itik Manila (Cairina moschata)," Jurnal Ilmiah Peternakan, vol. 1, no. 3, pp. 1086-1094, 2013.

[16] Soeparno, Ilmu dan Teknologi Daging. Yogyakarta: Gadjah Mada University Press, 1994.

[17] S. Simanullang, "Bobot potong, edible dan non edible itik peking mojosari putih (PmP) pada pemberian pakan sisa rumah makan dan komersial," Jurnal Ilmiah Peternakan, vol. 14 , no. 2 , pp. $87-89,2015$.

[18] R. Dewanti, M. Irham, and Sudiyono, "Pengaruh penggunaan enceng gondok (eichornia crassipes) terfermentasi dalam ransum terhadap persentase karkas, non-karkas, dan lemak abdominal itik lokal jantan umur delapan minggu," Buletin Peternakan, vol. 37, no.1, pp. 19-25, 2013.

[19] A. S. Andoko, Beternak Itik Pedaging. Jakarta: Agromedia Pustaka, 2016.

[20] M. Purba and L. H. Prasetyo, "Respon Pertumbuhan dan Produksi Karkas Itik Pedaging EPMp terhadap Perbedaan Kandungan Serat Kasar dan Protein dalam Pakan," Jurnal Ilmiah Peternakan, vol. 19, no. 3, pp. 220-230, 2014.

[21] M. Irham, "Pengaruh penggunaan enceng gondok (Eichornia crassipes) fermentasi dalam ransum terhadap persentase karkas, non karkas dan lemak abdominal itik lokal jantan umur delapan minggu," Master Thesis, Fakultas Pertanian, Universitas Sebelas Maret, 2012.

[22] R. Dewanti, "Pengaruh Pejantan dan Pakan terhadap Karkas dan Lemak Abdominal Itik Turi Umur Delapan Minggu," in Proceedings of The National Conference, 2012.

[23] S. Dharmawati and J. K. Ari, "Pengaruh penggunaan tepung daun alang alang (imperata cylindrica) dalam ransum terhadap kadar lemak, kolesterol karkas dan organ pencernaan itik alabio jantan," Ziaraa'ah, vol. 34, no. 2, pp. 150-160, 2012. 
[24] A. Kurniawan, M. Mufti, and I. H. Sulistyawan, "Bobot dan persentase lemak abdomen dan giblet itik lokal afkir berdasarkan sistem pemeliharaan dan lokasi yang berbeda," Jurnal Ilmiah Peternakan, vol. 2, no. 1, pp. 119-128, 2014. 